\title{
A Relational Foundation of Knowledge Production: Advice-Seeking in Knowledge-Based Organizations
}

\author{
MÁTÉ BAKSA* \\ ${ }^{*}$ Corvinus University of Budapest, Department of Organizational Behavior; \\ mate.baksa@uni-corvinus.hu
}

DOI: 10.14267/978-963-503-867-1_07

\begin{abstract}
In the past decade, the revolutionary advancement of technology brought the attention of academics and management practitioners to the innovative capability of organizations. Companies in knowledgeintensive industries increasingly focus on their ability of self-renewal and adaptation. Concurrently, organizational processes that support the amassment, management, sharing, and employment of knowledge have grown in importance. Organizational social network analysis provides the apparatus to explore knowledge networks in organizations by identifying relationships through which knowledge and information flow. Advice-seeking relationships have an essential role in knowledge production as they enable actors to acquire information, professional support, and knowledge elements they can recombine to form new knowledge. Advice-seeking always assumes trust between actors: by asking for help, one necessarily exposes their weakness to the other. What other relational conditions might there be of advice-seeking in organizational knowledge networks? What are the prerequisites for asking for help? In this paper, I examine the case of two knowledge-based organizations, both located in Hungary: (1) a business services center (390 employees) that offers professional services to B2B partners and (2) a higher education institution (583 employees). I analyzed data collected by a Budapest-based management consultancy that specializes in organizational social network research. I found that most independent variables were significant in the regression models. However, there was a notable difference between each variable's relative explanatory power in the two cases. While process- and decisionrelated relationships seemed essential in the business services center, informal communication and interpersonal trust were more critical for advice-seeking relationships to form in the higher education institution.
\end{abstract}

Keywords: knowledge networks, social network analysis, advice-seeking, knowledge sharing

Funding: The present publication is the outcome of the project "From Talent to Young Researcher project aimed at activities supporting the research career model in higher education,"identifier EFOP3.6.3-VEKOP-16-2017-00007 co-supported by the European Union, Hungary, and the European Social Fund. 


\section{Introduction}

Intensifying global competition has drawn managerial and scholarly attention to the innovative capability of organizations. Companies in the knowledge-based economy put particular efforts into developing their ability to renew and adapt to remain competitive (Csedő et al., 2018; Csedő \& Zavarkó, 2019). Their necessity to become and remain innovative has made the tasks of accumulating, managing, sharing, and applying organizational knowledge more significant than ever before (Bencsik \& Juhász, 2018).

In the past decades, various studies have investigated the development of organizational knowledge management systems (Anand et al., 2007; Natalicchio et al., 2017) as well as the requirements and success criteria for their effective functioning (Bencsik \& Sólyom, 2012; Mas-Machuca \& Martínez-Costa, 2012). Previous studies have also highlighted that the conditions of innovation production have changed considerably: new intellectual content is generated through the collective thinking and cooperation between people with different knowledge (Cheng et al., 2019; Faraj et al., 2015). All of this represents a significant shift from the images of the lonely polymath inventors of the Renaissance or the systematic but still solitary scientists of the Enlightenment and early modernity. Collaborating and knowledge-sharing groups and networks of people have taken the lead (Csontos \& Szabó, 2019).

Effective interpersonal knowledge sharing is one of the most important domains of knowledge management systems. It ensures that the wide range of knowledge present in organizations is available in the right place and at the right time (Park \& Kim, 2018). Therefore, successful knowledge sharing in high value-added, knowledge-based organizations is a precondition of competitiveness (Vohra \& Thomas, 2016). Knowledge sharing is, in many ways, a unique organizational phenomenon. Although it can be influenced by structural incentives (e.g., prizes, cash rewards), people cannot be forced to share their knowledge (Bordia et al., 2006). To facilitate knowledge-sharing, various organizational conditions should be met. One party should recognize their own lack of knowledge and seek advice from another. This requires not only the visibility of the other party's expertise but also their availability, accessibility, and the trust needed to address them (Mas-Machuca \& Martínez-Costa, 2012).

In this paper, I explore the relational conditions of advice-seeking. In doing so, I seek to answer the question of what factors decide to whom members of a knowledge-based organization turn if they need advice. To answer this question, I examined two samples of organizational social network data and used binary logistic regression to identify the most significant relational factors. I conclude that perceived trustworthiness, information, and helpfulness, as well as regular informal communication are all substantial for the 
occurrence of advice-seeking behavior - but with a notable difference between the relative explanatory power of each variable in the two samples.

\section{Theoretical background}

Previous research in the analysis of knowledge networks investigates three observational levels: (i) interpersonal knowledge networks, (ii) intra-organizational (inter-unit) knowledge networks, and (iii) inter-organizational knowledge networks (Csontos \& Szabó, 2019). In this paper, I focus on interpersonal knowledge networks, including the analysis of advice-seeking and knowledge-sharing relationships between network actors. From a network perspective, the actors (nodes) of a knowledge and innovation network are the employees and other stakeholders of the organization, and the relationships (ties) between them represent advice-seeking and cooperation. In these directed or reciprocal (one-way or two-way) relationships, information and emotions flow (Borgatti et al., 2014).

With the tools of organizational network analysis, we are able to analyze patterns of interpersonal interactions in various social networks (Vohra \& Thomas, 2016). A knowledge network is a system of interrelated actors whose primary purpose is to share the knowledge possessed by other actors and create new knowledge (Škerlavaj et al., 2010; Tortoriello et al., 2012). In knowledge networks, an actor may fulfill three functions. First, they might be a knowledge repository (i.e., a knowledge owner) possessing different knowledge elements. Second, they might be an active contributor to the acquisition and transfer of knowledge (i.e., a knowledge broker). Third, might also be the creator of new knowledge elements (i.e., an inventor). Relationships in a knowledge network also serve three functions. First, they are channels through which information flows (Borgatti et al., 2009), and second, they are tools that help to combine knowledge (Škerlavaj et al., 2010). Third, they are filters through which actors view, perceive, and evaluate each other's knowledge (Borgatti \& Cross, 2003).

In a knowledge network, a focal actor (ego) may choose from the members of two groups when asking for advice. They either seek out acquaintances within their existing personal network, or they may turn to actors with whom they have neither personal nor professional relationships but whose knowledge potential they recognized (Nebus, 2006). According to Borgatti and Cross (2003), egos' perception of another actor also influences whom they turn to for knowledge: their judgment is formed by conversations, observations, and other people's opinions.

The visibility of professional expertise strongly influences whom a focal actor turns to for advice (Leonardi, 2015). A network actor seeking advice should also be aware of where 
knowledge is accumulating within the organization and which other actor can help them with a particular issue, that is, who knows what. Borgatti and Cross (2003) also emphasize the significance of knowledge-related judgments. They argue that an advice seeker is more likely to turn to a co-worker for advice if they consider their knowledge valuable.

Considering interpersonal relationships, previous studies have shown that advice seekers often turn to people who are sympathetic to them rather than actual knowledge owners. In their study, Casciaro and Lobo (2005) examined the work choice preference of employees: they wished to know if sympathy or competence is more important. Based on their research findings, personal emotions play a more substantial role in the formation of work-related relationships than the degree of competence. If an employee is disliked, others will be reluctant to work with them, regardless of their visible professional competence (Casciaro \& Lobo, 2005). The selection of the knowledge owner is also affected by the subject of knowledge itself and the nature of the task to be solved. If the task is wellstructured and clear to the seeker, they can better assess the knowledge required for the solution, and this can narrow the range of potential knowledge owners (Nebus, 2006).

Although these previous studies have shown the significance of different relational factors (i.e., layers of the multiplex social reality), their direct effect on advice-seeking behavior remains to be determined. In this paper, the direct contribution of perceived trustworthiness, information, helpfulness, and informal communication is measured in the case of two knowledge-intensive organizations.

\section{Methods}

To answer my research question, I analyzed network data from two knowledge-intensive organizations based in Hungary. Information on the samples (including informal communication network structure) is summarized in Figure 1. The data was collected by Maven Seven Network Research, Inc., a Budapest-based consultancy specialized in organizational network analysis, between 2015 and 2017. The data was anonymized before provided for research purposes. Sample company \#1 operates in the business services sector, while sample company $\# 2$ is a higher education institution. 
Figure 1: Data on sample organizations

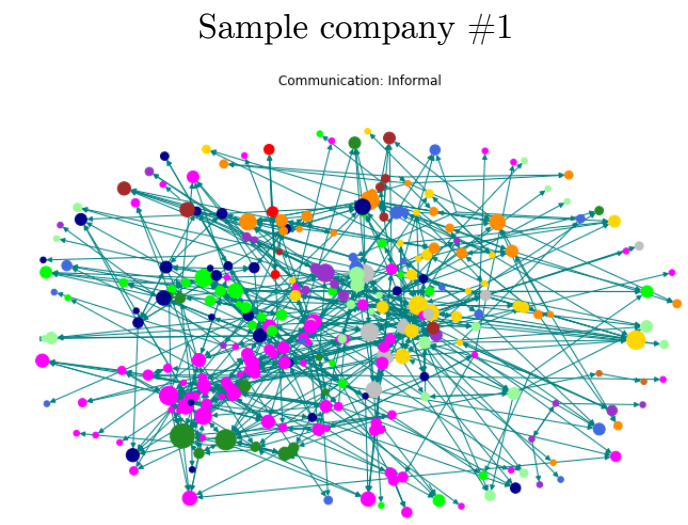

Hungary

Business Services Center

390 employees
Sample company $\# 2$

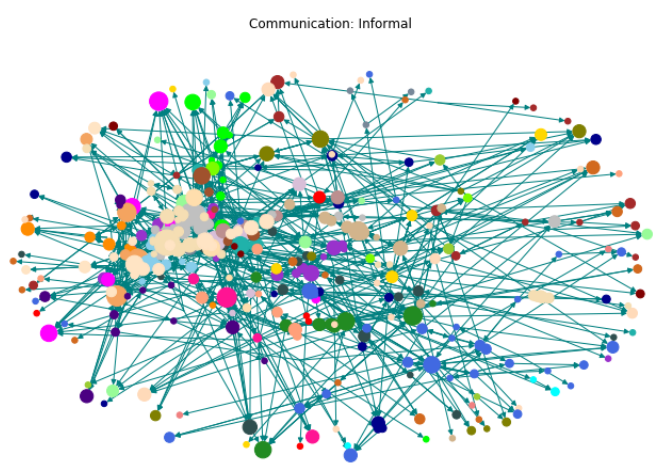

Hungary

Higher Education Institution 583 employees

Source: own editing (Note: in the informal communication networks, colors represent divisional affiliation while node size is proportional with in-degree centrality, i.e., the number of incoming ties)

The two datasets contain network data based on the same self-administered questionnaire in which respondents were asked to name 0-4 co-workers for 18 items. These items are related to different layers of interpersonal relationships and employees' perceptions about each other. Of these layers, five were examined in my analysis at a dyadic level, together with demographic data (division and hierarchy level) and Likert-scale data (formal communication quality). The five relational dimensions (and related survey questions) are as follows:

a) Trustworthy (perceived): Which of your colleagues do you consider trustworthy and dependable?

b) Helpful (perceived): Which of your colleagues is always ready or willing to help others?

c) Informal communication (actual): With whom do you have informal conversations about changes in the organization and processes?

d) Well-informed (perceived): Whom do you consider to be well informed with access to the latest news and updates?

e) Advice-seeking (actual): Whom do you feel comfortable asking for help if you find your work challenging? 
In dyad-level models, the unit of analysis is not an actor but a pair of actors. In this model, an observation is an $i j$ directed dyad, and variables indicate whether actor $i$ chose actor $j$ in a specific relationship dimension. The theoretical maximum of dyads is $n^{*}(n$ 1 ), of which an empirical maximum of $4 n$ could be realized as respondents could name 04 co-workers for each survey question. I used binary logistic regression to evaluate the effects of different relationship types on the emergence of advice-seeking relationships. Data were analyzed by SPSS Statistics 25.

\section{Results}

Binary logistic regression is a type of regression in which the dependent variable is binary $(0,1)$ while independent variables can be nominal, ordinal, or scale variables. It is based on chance rather than probability and assumes a large enough sample size, no multicollinearity between variables, and no extreme values. In my two samples, these assumptions were tested to be true. The regression model included one dependent variable (advice-seeking) and seven independent variables: (a) trustworthiness, (b) perception on information, (c) helpfulness, (d) informal communication between actors, (e) difference in division, (f) difference in the hierarchy, and (g) formal communication quality. Variables (a-e) assume 0 if a relationship is not realized and 1 if it did. Variable (f) assumes value from a $\{-1 ; 0 ; 1\}$ set based on actor i's hierarchic difference from actor $\mathrm{j}$. Variable (g) assume value on a 1-5 interval based on actor's perception.

The explanatory power of the independent variables is summarized in Table 1. The binary logistic regression models had an overall explanatory power between 0,314 (Cox \& Snell $\mathrm{R}^{2}$ ) and 0,424 (Nagelkerke $\mathrm{R}^{2}$ ) in the case of sample company $\# 1$ and 0,240 (Cox \& Snell

$\mathrm{R}^{2}$ ) and 0,371 (Nagelkerke $\mathrm{R}^{2}$ ) in the case of sample company \#2. This model primarily includes variables that model the relational foundations of advice-seeking behavior in organizations and explains about one-third of the total variance. Other internal (individual personality) and external (e.g., organizational structure, culture, and workplace layout) factors are accountable for the rest. 
Table 2: Summary of binary logistic regression model

\begin{tabular}{lcccr}
\hline Variables & \# Sig. & $\# 1 \operatorname{Exp}(\mathrm{B})$ & $\# 2$ Sig. & $\# 2$ Exp(B) \\
\hline (a) Trustworthy & .000 & 2.698 & .000 & 2.215 \\
(b) Well-informed & .000 & 5.153 & .020 & 1.412 \\
(c) Helpful & .000 & 15.895 & .000 & 1.844 \\
(d) Informal communication & .000 & 18.944 & .000 & 4.059 \\
(e) Same division & .635 & .901 & .202 & 1.631 \\
(f) Difference in hierarchy & .692 & .785 & .486 & .922 \\
(g) Formal communication quality & .002 & 1.442 & .998 & .005 \\
\hline
\end{tabular}

Source: own compilation

Relational variables (a-d) were significant in both organizational settings with high explanatory power. In sample company \#1 egos's perception of the alter's trustworthiness, information, helpfulness, and the existence of regular informal communication between them make the realization of advice-seeking behavior in the dyad more likely by 2.698 times, 5.153 times, 15.895 times, and 18.944 times, respectively. It seems that in the business services center, the alter's helpfulness and regular informal communication were the most significant when deciding whom to turn advice for. On the other hand, in sample company \#2, information (1.412) and helpfulness (1.844) were less critical than trustworthiness (2.215) and informal communication (4.059). Differences in division or hierarchy were not significant in either sample. Formal communication quality was significant in sample company $\# 1$ (with the low explanatory power of 1.442 ) but not in sample company $\# 2$.

Based on these samples, it seems that relational dimensions that were supposed to be connected to advice-seeking and knowledge-sharing behavior do explain the appearance of these phenomena. Their difference through the samples may suggest that specific relational dimensions (i.e., layers of the social reality) are more important in this regard in one organization and less in the other. 


\section{Discussion and recommendations}

In this paper, I examined two knowledge-intensive organizations operating in Hungary. Based on previous findings of Casciaro and Lobo (2005) and Mas-Machuca and MartínezCosta (2012), I set out to investigate the relational foundations of advice-seeking relationships. I used data from self-administered social network survey questionnaires and analyzed it on a dyadic level. In this way, I built a binary logistic regression model that explains about one-third of the total variance of the realization of advice-seeking in both organizational samples. In accordance with prior literature, I found that a regular social connection (i.e., informal communication) is significant and the alter's perceived trustworthiness, helpfulness, and information are also essential factors in the formation of advice-seeking ties.

Differences in the explanatory power of the relational variables between the two samples might be due to the different organizational cultures and operational contexts. In a forprofit organization (e.g., a business services center), people are working together and are thus interested in collaboration, knowledge sharing, and advice-seeking. In academia, however, faculty members are working in a competitive environment as they work together but they are competitors at the same time. This may lead to an increased importance of trustworthiness and a decreased explanatory power of other layers of interpersonal relationships.

In conclusion, management practitioners in knowledge-intensive organizations, such as the ones I examined, can increase the likelihood of knowledge sharing by reinforcing trust among employees. They can as well create opportunities for workers to make their expertise visible or formulate and maintain informal relationships. An incentive system that rewards co-workers helping each other may also lead to a higher willingness to advise, which will, in turn, result in a higher probability of asking for help. Through these measures, managers may create an organizational environment that would foster adviceseeking and knowledge sharing and generate innovation. 


\section{References}

Anand, N., Gardner, H. K., \& Morris, T. (2007). Knowledge-Based Innovation: Emergence and Embedding of New Practice Areas in Management Consulting Firms. Academy of Management Journal, 50(2), 406-428. https://doi.org/10.5465/amj.2007.24634457

Bencsik, A., \& Juhász, T. (2018). Tudásorientált szervezetek értékítélete a bizalom gazdasági hatásairól. Vezetéstudomány / Budapest Management Review, 49(1), 30-39. https://doi.org/10.14267/veztud.2018.01.04

Bencsik, A., \& Sólyom, A. (2012). Jön, megy vagy marad? A tacit tudás megőrzésének lehetősége a szervezetben. Munkaügyi Szemle, 56(3), 21-32.

Bordia, P., Irmer, B. E., \& Abusah, D. (2006). Differences in sharing knowledge interpersonally and via databases: The role of evaluation apprehension and perceived benefits. European Journal of Work and Organizational Psychology, 15(3), 262-280. https://doi.org/10.1080/13594320500417784

Borgatti, S. P., Brass, D. J., \& Halgin, D. S. (2014). Social Network Research: Confusions, Criticisms, and Controversies. In Contemporary Perspectives on Organizational Social Networks (pp. 1-29). https://doi.org/10.1108/s0733-558x(2014)0000040001

Borgatti, S. P., \& Cross, R. (2003). A Relational View of Information Seeking and Learning in Social Networks. Management Science, 49(4), 432-445. https://doi.org/10.1287/mnsc.49.4.432.14428

Borgatti, S. P., Mehra, A., Brass, D. J., \& Labianca, G. (2009). Network Analysis in the Social Sciences. Science, 323(5916), 892-895. https://doi.org/10.1126/science.1165821

Casciaro, T., \& Lobo, M. S. (2005). Competent jerks, lovable fools, and the formation of social networks. Harvard Business Review, 83(6), 92-99, 149.

Cheng, J.-H., Huang, J.-K., Zhao, J., \& Wu, P. (2019). Open Innovation: The Role of Organizational Learning Capability, Collaboration, and Knowledge Sharing. International Journal of Organizational Innovation, 11(3), 260-272.

Csedő, Z., \& Zavarkó, M. (2019). Változás, tudás és innováció a vezetéstudományban: elméleti modellek elemzése és értelmezése. Vezetéstudomány / Budapest Management Review, 50(12), 173-184. https://doi.org/10.14267/veztud.2019.12.15

Csedô, Z., Zavarkó, M., \& Sára, Z. (2018). A vállalati innováció által indukált szervezeti változások a magyar energiaszektorban. Vezetéstudomány / Budapest Management Review, 49(2), 53-62. https://doi.org/10.14267/veztud.2018.02.06

Csontos, R. S., \& Szabó, Z. R. (2019). Hálózati tanulás - tanuló hálózatok. Vezetéstudomány / Budapest Management Review, 50(1), 2-13. https://doi.org/10.14267/veztud.2019.01.01

Faraj, S., Kudaravalli, S., \& Wasko, M. (2015). Leading Collaboration in Online Communities. MIS Quarterly, 39(2), 393-412. https://doi.org/10.25300/misq/2015/39.2.06

Leonardi, P. M. (2015). Ambient Awareness and Knowledge Acquisition: Using Social Media to Learn "Who Knows What" and "Who Knows Whom." MIS Quarterly, 39(4), 747-762. https://doi.org/10.25300/misq/2015/39.4.1 
Mas-Machuca, M., \& Martínez-Costa, C. (2012). Exploring critical success factors of knowledge management projects in the consulting sector. Total Quality Management $\mathscr{E}$ Business Excellence, 23(11-12), 1297-1313. https://doi.org/10.1080/14783363.2011.637778

Natalicchio, A., Ardito, L., Savino, T., \& Albino, V. (2017). Managing knowledge assets for open innovation: a systematic literature review. Journal of Knowledge Management, 21(6), 1362-1383. https://doi.org/10.1108/jkm-11-2016-0516

Nebus, J. (2006). Building Collegial Information Networks: A Theory of Advice Network Generation. Academy of Management Review, 31(3), 615-637. https://doi.org/10.5465/amr.2006.21318921

Park, S., \& Kim, E.-J. (2018). Fostering organizational learning through leadership and knowledge sharing. Journal of Knowledge Management, 22(6), 1408-1423. https://doi.org/10.1108/jkm-10-2017-0467

Škerlavaj, M., Dimovski, V., \& Desouza, K. C. (2010). Patterns and Structures of Intraorganizational Learning Networks within a Knowledge-Intensive Organization. Journal of Information Technology, 25(2), 189-204. https://doi.org/10.1057/jit.2010.3

Tortoriello, M., Reagans, R., \& McEvily, B. (2012). Bridging the Knowledge Gap: The Influence of Strong Ties, Network Cohesion, and Network Range on the Transfer of Knowledge Between Organizational Units. Organization Science, 23(4), 1024-1039. https://doi.org/10.1287/orsc.1110.0688

Vohra, N., \& Thomas, N. (2016). Investigating Organizational Learning through Social Network Analysis: The Case of a Consultancy Firm in India. Thunderbird International Business Review, 58(6), 587-600. https://doi.org/10.1002/tie.21777 